medRxiv preprint doi: https://doi.org/10.1101/2020.04.24.20078295; this version posted June 8, 2020. The copyright holder for this preprint (which was not certified by peer review) is the author/funder, who has granted medRxiv a license to display the preprint in perpetuity.

All rights reserved. No reuse allowed without permission.

1 Cell-density independent increased lymphocyte production and loss rates post-autologous

2

\title{
hematopoietic stem cell transplantation
}

Mariona Baliu-Piqué ${ }^{*}$, Vera van Hoeven ${ }^{2 *}$, Julia Drylewicz ${ }^{1^{*}}$, Lotte E. van der Wagen ${ }^{3}$, Anke Janssen ${ }^{1}$, Sigrid A. Otto ${ }^{1}$, Menno C. van Zelm ${ }^{4}$, Rob J. de Boer ${ }^{5}$, Jürgen Kuball ${ }^{1,3}$, José A.M. Borghans ${ }^{1 *}$ and Kiki Tesselaar $^{1 *}$

${ }^{1}$ Center for Translational Immunology, University Medical Center Utrecht, The Netherlands;

${ }^{2}$ Department of Experimental Immunology, Amsterdam UMC, University of Amsterdam, The Netherlands;

${ }^{3}$ Department of Hematology, University Medical Center Utrecht, The Netherlands;

${ }^{4}$ Department of Immunology and Pathology, Monash University and Alfred Hospital, Melbourne;

${ }^{5}$ Theoretical Biology, Utrecht University, Utrecht, The Netherlands

*These authors contributed equally to this work

\section{Corresponding author:}

Kiki Tesselaar, PhD

Center for Translational Immunology

University Medical Center Utrecht (UMCU)

P.O. Box 85090, 3508 AB Utrecht, The Netherlands

T: +31 (0)88755394; E-mail: K.Tesselaar@umcutrecht.nl

\section{Abstract}

Lymphocyte numbers need to be quite tightly regulated. It is generally assumed that lymphocyte production and survival rates increase homeostatically when lymphocyte numbers decrease. This widely-accepted concept is largely based on experiments in mice. In humans, lymphocyte reconstitution usually occurs very slowly, which challenges the idea that density dependent homeostasis aids recovery from lymphopenia. Using in vivo deuterium labelling, we quantified lymphocyte production and survival rates in patients who underwent an autologous hematopoietic stem cell transplantation (autoHSCT). We indeed found that the production rates of most T-cell and B-cell subsets in autoHSCT-patients were 2 to 8 -times higher than in healthy controls. These increased lymphocyte production rates went hand in hand with a 3 to 9-fold increase in cell loss rates, and both rates did not normalize when cell numbers did. This challenges the concept of homeostatic regulation of lymphocyte production and survival rates in humans. 
medRxiv preprint doi: https://doi.org/10.1101/2020.04.24.20078295; this version posted June 8, 2020. The copyright holder for this preprint (which was not certified by peer review) is the author/funder, who has granted medRxiv a license to display the preprint in perpetuity.

All rights reserved. No reuse allowed without permission.

\section{Introduction}

Under healthy conditions, the peripheral T- and B-cell populations are maintained at relatively stable numbers throughout life ${ }^{1,2}$. Homeostatic mechanisms are thought to regulate lymphocyte production and survival rates in a density-dependent manner. Indeed, studies in rodents have shown that lymphocyte division and survival rates increase in response to severe lymphopenic conditions ${ }^{3}$. Robust peripheral proliferation of T-cells occurs both upon adoptive cell transfer into severely lymphocyte-depleted mice, and in partially immune-depleted hosts in the absence of adoptive cell transfer, a phenomenon termed lymphopenia-induced proliferation (LIP) ${ }^{3-6}$. Similarly, rapid proliferation and extended survival of B-cells occur after adoptive cell transfer into B-cell deficient hosts and correlate with peripheral B-cell numbers ${ }^{7}$.

In analogy, it is generally assumed that lymphopenic conditions induce alterations in lymphocyte dynamics in humans. However, in humans full recovery of the T-cell compartment following an autologous hematopoietic stem cell (autoHSCT) is notoriously slow, often taking several years ${ }^{8-11}$. On the basis of elevated frequencies of $\mathrm{Ki}-67^{+}$cells, severe lymphopenia arising after HSCT and lymphocyte-depleting treatments has been associated with increased proliferation of naive and memory T-cells ${ }^{12-15}$. However, elevated frequencies of $\mathrm{Ki}-67^{+}$cells were shown to decline within 3 to 6 months after cell depletion, despite the fact that patients were still deeply lymphopenic ${ }^{13-15}$. Furthermore, increased T-cell proliferation rates after allogeneic HSCT have been shown to correlate with the occurrence of graft-versus-host disease (GVHD) and infectious-disease-related complications ${ }^{14}$. Together, these observations question whether homeostatic mechanisms are induced to compensate for low lymphocyte numbers in humans undergoing HSCT. It remains unclear to what extent increased T-cell proliferation post-HSCT reflects a T-cell density-dependent response to lymphopenia, or an immune response triggered by therapy-related tissue damage, infectious complications, or immune activation.

To elucidate whether lymphocyte production and death rates in humans are regulated in a density-dependent manner, we used in vivo deuterium labelling to quantify the production and loss rates of different T- and B-cell subsets in patients who received an autologous HSCT (autoHSCT), and had no signs of clinically manifested infections or GVHD. Twelve months after autoHSCT, absolute numbers of $\mathrm{CD}^{+} \mathrm{T}$-cells and memory and natural effector B-cells in these patients were still lower than in healthy individuals, while $\mathrm{CD} 8^{+} \mathrm{T}$-cell and naive B-cell numbers had already recovered to healthy control values. Deuterium labelling revealed that the production rates of most lymphocyte subsets, even those that had already reconstituted, were significantly higher in patients post-autoHSCT than in healthy individuals. These increased rates of T- and B-cell production could only be reconciled with the 
medRxiv preprint doi: https://doi.org/10.1101/2020.04.24.20078295; this version posted June 8, 2020. The copyright holder for this preprint (which was not certified by peer review) is the author/funder, who has granted medRxiv a license to display the preprint in perpetuity.

All rights reserved. No reuse allowed without permission.

observed slow changes in lymphocyte numbers over time if lymphocyte loss rates were also significantly increased, impeding a timely reconstitution of the lymphocyte pool post-autoHSCT.

\section{Materials and Methods}

Complete Materials and Methods can be found as Supplementary Information.

\section{Patient characteristics}

Six patients who received an autoHSCT for the treatment of a hematologic malignancy were enrolled in the study after having provided written informed consent. Following repeated subcutaneous injections with granulocyte-colony stimulating factor (G-CSF), stem cells were obtained by leukapheresis of peripheral blood. Patients received a non T-cell depleted graft; the average number of $\mathrm{CD} 4^{+}$cells transplanted was $5.03 \times 10^{6}$ cells $/ \mathrm{kg}$ (median, 4.12; range, 1.82-12.38). Patients were included in the study between 196 and 420 days after autoHSCT, and had no signs of transplantationrelated complications, severe infections (HIV, HBV, HCV), other liver disease, active uncontrolled infections (such as infectious mononucleosis), inadequate liver or kidney function, or cardiovascular disease before and during the study. Additional inclusion criteria were: fully transfusion-independent at start of the study, hemoglobin level $\geq 6 \mathrm{mmol} / \mathrm{I}$, and platelet count $\geq 50 \times 10^{9} / \mathrm{L}$. Any use of medication during the study was unrelated to the malignancy and the HSCT (Figure 1). In order to compare the phenotypes of the B-and T-cell compartments of patients to those of age-matched healthy individuals, we used data from healthy individuals from a previous study ${ }^{16}$, and additional blood samples were collected from healthy volunteers not following the labelling protocol after having provided informed consent. This study was approved by the medical ethical committee of the University Medical Center Utrecht and conducted in accordance with the Helsinki Declaration.

\section{In vivo deuterium labelling}

In vivo deuterium labelling was performed as previously described with small adaptations ${ }^{16}$. Briefly, patients received an oral ramp-up dose of $7.5 \mathrm{ml}$ of heavy water $\left({ }^{2} \mathrm{H}_{2} \mathrm{O}, 99.8 \%\right.$ enriched, Cambridge Isotope Laboratories) per kg body water on the first day of the study, and drank a daily maintenance dose of $1.25 \mathrm{ml}^{2} \mathrm{H}_{2} \mathrm{O}$ per kg body water for 6 weeks. To reduce the study burden, the labelling period of patients was 3 weeks shorter than the previously used labelling period for healthy individuals.

\section{Cell isolation, flow cytometry and cell sorting}

Peripheral blood mononuclear cells were obtained by Ficoll-Paque (GE Healthcare, Little Chalfont, UK) density gradient centrifugation from heparinized blood. Granulocytes were obtained by 2 cycles of erythrocyte lysis $(155 \mathrm{mM} \mathrm{NH} 4 \mathrm{Cl}, 10 \mathrm{mM}$ KHCO3, $0.1 \mathrm{mM} \mathrm{Na2-EDTA}, \mathrm{pH}=7.0)$ of the 
medRxiv preprint doi: https://doi.org/10.1101/2020.04.24.20078295; this version posted June 8, 2020. The copyright holder for this preprint (which was not certified by peer review) is the author/funder, who has granted medRxiv a license to display the preprint in perpetuity.

All rights reserved. No reuse allowed without permission.

granulocyte/erythrocyte layer. To determine baseline enrichment, total peripheral blood mononuclear cells were frozen on the first day of the study, prior to ${ }^{2} \mathrm{H}_{2} \mathrm{O}$ intake.

Absolute cell numbers were determined using TruCount tubes (BD Biosciences, San Jose, CA, USA), and cell cycle analysis was performed by measuring expression of Ki-67. Samples were analysed on an LSR-II or LSR-Fortessa flow cytometer using FACS Diva software (BD Biosciences).

CD19 ${ }^{+}$naive $\left(\operatorname{IgM}^{+} \mathrm{CD} 27^{-}\right)$, Ig class-switched $\left(\operatorname{IgM}^{-} \mathrm{CD} 27^{+}\right)$and $\operatorname{IgM}^{+}\left(\operatorname{IgM}^{+} \mathrm{CD} 27^{+}\right)$memory B-cells and $\mathrm{CD}^{+} \mathrm{CD}^{+}$and $\mathrm{CD3}^{+} \mathrm{CD}^{+}$naive $\left(\mathrm{CD} 27^{+} \mathrm{CD} 45 \mathrm{RO} \mathrm{O}^{-}\right)$and memory $\left(\mathrm{CD} 45 \mathrm{RO}^{+}\right)$T-cells were sorted on a FACSAria II or FACSAria III cell sorter using FACS Diva software (BD Biosciences). Flow cytometric analyses and cell sorting were always performed on freshly isolated material. Representative density dot plots and the gating strategy for TruCount analysis and cell sorting are shown in Sup. Figure 1.

\section{Statistical analyses}

Medians were compared between groups using Mann-Whitney tests. Correlations were analysed using the Spearman's rank test (GraphPad Software, Inc). Differences with a $p$-value $<0.05$ were considered significant.

\section{Results}

\section{Heterogeneous T-cell reconstitution kinetics post-autoHSCT}

To investigate whether lymphocyte production and loss depend on cell numbers during lymphopenia in humans, we quantified the production and loss rates of B-and T-cells in 6 patients who received an autoHSCT for the treatment of haematological malignancies. Patients were included in the study between 196 days and 420 days post-autoHSCT, they received deuterated water $\left({ }^{2} \mathrm{H}_{2} \mathrm{O}\right)$ for six weeks, and were followed for approximately one year after start of the labelling period (Figure 1). Patient $B$ withdrew from the study 10 weeks after the start of ${ }^{2} \mathrm{H}_{2} \mathrm{O}$ labelling due to infectious complications unrelated to participation in the study. All other patients had no complications that needed treatment during the study follow-up, which was supported by CRP levels in the normal range (Sup. Figure 2).

The sub-optimal T-cell recovery observed in the peripheral blood of patients post auto-HSCT (Figure 2A) was largely due to the slow reconstitution of $\mathrm{CD} 4^{+} \mathrm{T}$-cells (Figure 2B). At the start of ${ }^{2} \mathrm{H}_{2} \mathrm{O}$ labelling, $\mathrm{CD} 8^{+} \mathrm{T}$-cell numbers had reached normal levels in most patients, whereas $\mathrm{CD} 4^{+} \mathrm{T}$-cell numbers remained below normal levels even 1.5 years post-autoHSCT. This resulted in an inverse CD4:CD8 ratio in all patients except for patient $C$ (Figure $2 C$ ), who experienced extremely slow $C D 8^{+} T-$ cell reconstitution (Figure 2D). Naive $\left(\mathrm{CD}^{2} 5 \mathrm{RO}^{-} \mathrm{CD} 27^{+}\right) \mathrm{CD}^{+} \mathrm{T}$-cell numbers remained below normal levels throughout the 2-year follow-up period, whereas memory $\left(\mathrm{CD} 45 \mathrm{RO}^{+}\right) \mathrm{CD} 4^{+} \mathrm{T}$-cells reached the 
medRxiv preprint doi: https://doi.org/10.1101/2020.04.24.20078295; this version posted June 8, 2020. The copyright holder for this preprint (which was not certified by peer review) is the author/funder, who has granted medRxiv a license to display the preprint in perpetuity.

All rights reserved. No reuse allowed without permission.

lower range of normal levels around 400 days post-autoHSCT (Figure 2B). Naive and memory CD8 ${ }^{+} \mathrm{T}^{-}$ cell numbers were at normal or supra-normal levels at the start of the study in all patients except for patient $C$ (Figure 2D). In line with cell numbers, for most patients the fractions of naive cells, central memory (CM, CD45RO $\left.{ }^{+} \mathrm{CD} 27^{+}\right)$, effector memory (EM, CD45RO $\left.{ }^{+} \mathrm{CD} 27^{-}\right)$and effector (CD45RO-CD27-) $\mathrm{T}^{-}$ cells differed from those in healthy controls and varied slightly over time (Figure 2E and Sup. Figure 3).

Because it is generally assumed that during lymphopenia the availability of growth and survival factors increases, which has in particular been shown for IL-7 plasma levels ${ }^{18-22}$, we also determined plasma levels of IL-7 and IL-15 between 12 and 24 months post-autoHSCT. Despite the CD4+ ${ }^{+}$-cell lymphopenia observed in these patients, their plasma concentrations of IL-7 and IL-15 and several other cytokines were in the range of those of healthy controls (Sup. Figure 2).

\section{Increased $\mathrm{CD4}^{+}$and $\mathrm{CD} 8^{+} \mathrm{T}$-cell production rates post-autoHSCT}

To investigate whether low $\mathrm{CD}^{+}{ }^{+} \mathrm{T}$-cell numbers were associated with increased T-cell production rates, we compared the level of deuterium enrichment in the DNA of the different T-cell subsets between patients and controls. Deuterium enrichment analysis showed a relatively high level of label incorporation in patients, despite the fact that the labelling period was 3 weeks shorter for patients than for controls (Figure $3 \mathrm{~A}$ ). Using mathematical modelling we estimated the production rates of the different T-cell subsets (i.e. the number of new cells produced per day, coming from a source or peripheral cell division, divided by the number of resident cells in the population). We found that the production rates of naive and memory $\mathrm{CD}^{+} \mathrm{T}$-cells were, respectively, 6 -times and 3-times higher in patients than in controls. For naive and memory $\mathrm{CD} 8^{+} \mathrm{T}$-cells, the estimated production rates were approximately 8- and 4-times higher in patients compared to controls (Figure 3B, Sup. Table 1), despite the fact that absolute $\mathrm{CD} 8^{+} \mathrm{T}$-cell numbers had already recovered to healthy levels 12 months post-transplantation.

\section{Increased proliferation of naive but not memory $\mathrm{CD}^{+}$and $\mathrm{CD}^{+} \mathrm{T}$ cells}

T-cell production rates as measured by deuterium labelling may reflect cell division of the subset of interest or an influx of cells from a source (e.g. by thymic output) or from another subset (e.g. through lymphocyte differentiation). To distinguish between these options, we first measured Ki-67 expression, a marker for peripheral cell division, of all lymphocyte subsets. The fraction of Ki- $67^{+}$cells within the naive $\mathrm{CD}^{+}$and $\mathrm{CD} 8^{+}$T-cell pools was significantly higher in patients compared to controls (Figure 4A). For the memory T-cell subsets, in contrast, the fraction of $\mathrm{Ki}-67^{+}$cells of patients did not differ significantly from those of controls (Figure 4A). This suggests that the increased production rates of memory $\mathrm{CD}^{+}$and $\mathrm{CD} 8^{+} \mathrm{T}$-cells may occur due to an increased influx from naive T-cells into the memory compartment, rather than increased T-cell division within the memory T-cell pools. 
medRxiv preprint doi: https://doi.org/10.1101/2020.04.24.20078295; this version posted June 8, 2020. The copyright holder for this preprint (which was not certified by peer review) is the author/funder, who has granted medRxiv a license to display the preprint in perpetuity.

All rights reserved. No reuse allowed without permission.

Besides increased cell division in the naive T-cell pool, increased naive T-cell production rates post-autoHSCT could in theory also be due to increased thymic output. T-cell receptor excision circles (TRECS) are commonly measured to estimate thymopoiesis. Because the average TREC content per T-cell declines with age ${ }^{23-25}$, we measured TREC contents of naive T-cells from patients, cord blood, and young (on average 23 years of age) and aged (on average 68 years of age) healthy individuals ${ }^{16}$. The average TREC content of naive CD4 ${ }^{+}$T-cells in patients was approximately 10 -fold higher than in aged controls, and not significantly different from that of young individuals and cord blood (Figure 4B), even though all but one of the patients were more than 50 years of age. For naive $\mathrm{CD} 8^{+} \mathrm{T}$-cells, the average TREC content in patients was in the range of young and aged controls (Figure $4 B)$. We also measured $C D 31$ expression on naive $C D 4^{+} T$-cells, as $C D 31^{+} C D 4^{+} T$ cells are known to be enriched in recent thymic emigrants (RTEs) ${ }^{26,27}$. The fraction of $\mathrm{CD} 31^{+}$cells within the naive $\mathrm{CD} 4^{+} \mathrm{T}^{-}$ cell population was slightly higher in patients than in aged controls and slightly lower than in young controls and cord blood (Figure 4C, Sup. Figure 4). For naive T-cells, the combined Ki-67, TREC and CD31 data suggest that the increased T-cell production is due to increased T-cell division, and that the increased average TREC contents and percentages of $\mathrm{CD} 31^{+}$cells may be a direct consequence of normal thymic output entering a smaller T-cell pool ${ }^{28}$.

\section{Heterogeneous B-cell reconstitution kinetics post-autoHSCT}

Next, we studied the changes in B-cell dynamics following autoHSCT. Although total CD19+ Bcell numbers and naive ( $\left.\operatorname{IgM}^{+} \mathrm{CD} 27^{-}\right)$B-cell numbers had already reached normal or even supra-normal levels by day 200 post-autoHSCT, Ig class-switched (IgM-CD27 $7^{+}$) and $\operatorname{lgM}^{+}\left(\operatorname{IgM}^{+} C D 27^{+}\right)$memory B-cell numbers in most patients were still below, or in the lower range of, those of healthy controls throughout the study period (Figure 5A, 5B and Sup. Figure 5).

\section{Increased production rates of B-cells post-autoHSCT}

We analysed the deuterium enrichment of the different B-cell subsets to study whether B-cell production rates were increased for subsets which were still low in cell numbers (Figure 6A). The production rates of Ig switched-memory B-cells and IgM $\mathrm{IM}^{+}$memory B-cells were 3.5-times and 5-times higher than in controls, respectively (Figure 6B, Sup. Table 1). Also the production rate of naive B-cells, a population that had already reconstituted to supra-normal levels, remained significantly higher than in healthy controls (Figure 6B, Sup. Table 1).

Because B-cell production may depend on peripheral B-cell division and on de novo bone marrow output, we measured Ki-67 expression and kappa-deleting recombination excision circles (KRECs), in an attempt to estimate bone marrow output. The percentages of dividing, i.e. $\mathrm{Ki}-67^{+}$, cells within $\operatorname{lgM}^{+}$and Ig switched-memory B-cells were significantly higher in patients than in healthy 
medRxiv preprint doi: https://doi.org/10.1101/2020.04.24.20078295; this version posted June 8, 2020. The copyright holder for this preprint (which was not certified by peer review) is the author/funder, who has granted medRxiv a license to display the preprint in perpetuity.

All rights reserved. No reuse allowed without permission.

individuals (Figure 6C). In contrast, the fraction of $\mathrm{Ki}-67^{+}$cells within the naive B-cell subset was similar between patients and controls (Figure 6C). Although naive B-cell peripheral division rates were not increased post-autoHSCT, their production rates were 2-times higher than in controls. The replication history (measured as number of cell divisions) of the naive B-cell subsets in patients tended to be lower than in controls (although not significantly), suggesting that the output of naive B-cells from the bone marrow rather than their peripheral proliferation rate was increased after autoHSCT (Figure 6D).

\section{Increased lymphocyte production rates are counteracted by increased lymphocyte loss rates}

The increased lymphocyte production rates that we observed in patients after autoHSCT may at first sight suggest that, also in humans, lymphocyte production is regulated in a density-dependent manner. The observation that lymphocyte production rates were also elevated for subsets for which cell numbers had already normalized, however, challenges this interpretation. Another observation challenging this interpretation is that for most subsets, lymphocyte numbers increased very little over time, despite the significant increase in lymphocyte production. This suggests that lymphocyte loss rates were also significantly increased after autoHSCT.

To estimate the average loss rates of all lymphocyte subsets (i.e. the number of cells lost per day, by cell death, migration or differentiation, divided by the number of resident cells in the population), we used the average lymphocyte production rates estimated from the deuterium labelling experiments and an exponential function to describe the changes in cell numbers of each lymphocyte subset over time (see Sup. material and methods). For most T-cell and B-cell subsets the average loss rate was approximately 3 to 5 -times higher post-autoHSCT than in healthy individuals (Figure 7, Sup. Table 2). For naive $\mathrm{CD} 8^{+}$T-cells the average loss rate was even 9.5-times higher in patients than in healthy individuals (Figure 7, Sup. Table 2). Thus, despite the fact that production rates are clearly increased in patients post-autoHSCT, this increased production goes hand in hand with increased lymphocyte loss rates, thereby challenging the view that it reflects a homeostatic response to low lymphocyte numbers.

\section{Discussion}

From a homeostatic viewpoint, a response to low lymphocyte numbers could take the form of increased lymphocyte production or decreased lymphocyte loss. Based on the observation that severe lymphopenia in mice is associated with increased peripheral proliferation ${ }^{3-5,20}$, it is widely believed that lymphocyte production rates are increased when cell numbers are low. We have previously shown that naive T-cell turnover rates do not increase to compensate for the at least 10-fold decline in thymic output in elderly individuals ${ }^{16}$. This could be due to the relatively small degree of naive T-cell loss 
medRxiv preprint doi: https://doi.org/10.1101/2020.04.24.20078295; this version posted June 8, 2020. The copyright holder for this preprint (which was not certified by peer review) is the author/funder, who has granted medRxiv a license to display the preprint in perpetuity.

All rights reserved. No reuse allowed without permission.

observed during healthy ageing. Under more severe conditions of lymphopenia in humans, high frequencies of proliferating lymphocytes have been observed, but these have been linked to immune activation and clinical events, e.g. GVHD and opportunistic infections ${ }^{14}$. Thus, there is no convincing evidence that homeostatic regulation of lymphocyte production and loss occurs in humans.

Our deuterium labelling study shows that in patients receiving an autoHSCT, in the absence of GVHD, clinically manifested infections and transplantation-related complications, the production rates of most T- and B-cell subsets were significantly increased 12 months after transplantation. Increased lymphocyte production following lymphodepletion has generally been interpreted as evidence for a density-dependent response to low lymphocyte numbers ${ }^{12,13,15,29,30}$. Our study challenges this view for two reasons: i) T- and B-cell production rates did not normalize when cell numbers did, and ii) lymphocyte loss rates were also increased post-autoHSCT. This suggests that the increase in lymphocyte production rates in autoHSCT patients was not simply a homeostatic response to low cellnumbers. Other determinants, such as repertoire diversity or the clonality of the T-cell pool might also play a role. In addition, despite the fact that the patients in our study were included up to 12 months post-transplantation and were selected on the basis of being in good health, we cannot exclude that the increased rates of lymphocyte production and loss in these patients reflect HSCT-related complications, such as the impact of initial chemo-therapy and conditioning-therapy or sub-clinical infections and inflammation, which may have gone unnoticed.

The observation that lymphocyte loss rates were increased post-autoHSCT is remarkable in the light of the widely held view that homeostatic mechanisms could take the form of increased lymphocyte survival. This concept is supported by the observation that the availability of pro-survival and anti-apoptotic factors, such as IL-7 ${ }^{31}$, increases during lymphopenia. We found that lymphocyte loss rates were up to 10 -fold increased after autoHSCT. This is in line with previous human studies on T-cell survival after allogenic HSCT, which consistently reported that the fraction of pro-apoptotic cells increases following transplantation ${ }^{15,32-34}$. Although this suggests that intervention with lymphocyte survival after HSCT may aid lymphocyte reconstitution, in our study, different factors may have contributed to the loss of cells from the peripheral blood. Cells may have been lost from the circulation by cell death, but also by lymphocyte differentiation and/or migration to the tissues. Further studies need to clarify whether lymphocyte reconstitution occurs at similar rates in blood and tissues, or whether lymphocyte recruitment to the tissues may be a key factor influencing the loss of lymphocytes from the blood following autoHSCT.

Consistent with previous reports ${ }^{10,15,35}$, we found that 12 months post-autoHSCT, CD4 ${ }^{+}$T-cell numbers were below the normal range while $\mathrm{CD} 8^{+} \mathrm{T}$-cells recovered more rapidly. Deuterium labelling in patients revealed that the average production rates of most T-cell subsets were significantly increased following autoHSCT. This increase was especially evident for naive T-cells. The high 
medRxiv preprint doi: https://doi.org/10.1101/2020.04.24.20078295; this version posted June 8, 2020. The copyright holder for this preprint (which was not certified by peer review) is the author/funder, who has granted medRxiv a license to display the preprint in perpetuity.

All rights reserved. No reuse allowed without permission.

percentage of $\mathrm{Ki}-67^{+}$naive T-cells post-autoHSCT suggests that increased naive T-cell production is to a large extent explained by increased peripheral T-cell proliferation. Memory T-cell production rates (based on deuterium enrichment) were also higher in patients compared to controls, while Ki-67 expression suggested that memory $\mathrm{CD}^{+}$and $\mathrm{CD} 8^{+} \mathrm{T}$-cell proliferation rates were not increased after autoHSCT. This seeming contradiction may be explained by the fact that Ki-67, a snapshot marker, may be less sensitive to detect differences in T-cell proliferation than long-term in vivo deuterium labelling. Alternatively, the increased production rate of memory T cells post-autoHSCT may be due to increased transition of naive T cells into the memory T-cell population. In mice it has been demonstrated that naive T-cells adoptively transferred into immunodeficient animals can undergo division without cognate antigen stimulation, thereby acquiring a memory phenotype ${ }^{36,37}$.

If a significant part of cell production in a certain lymphocyte subset (e.g. the memory subset) is indeed due to an influx from another lymphocyte subset (e.g. the naive subset), the increased production rates that we observed may either reflect a true increase in cell production, or a normal influx of cells entering a smaller lymphocyte population. To distinguish between these options, for each lymphocyte subset and each individual, we also calculated the total number of cells produced per day (i.e. coming from a source and/or from peripheral cell division), by multiplying the average production rate of each lymphocyte subset with the median cell number of that subset, and compared these values to those in healthy controls (data not shown). We found that total daily lymphocyte production was as high as in healthy controls for naive $\mathrm{CD}^{+} \mathrm{T}$ cells and higher than in healthy controls for all other lymphocyte subsets, suggesting that the increased lymphocyte production rates postautoHSCT truly reflected increased T-cell proliferation and/or an increased influx from another lymphocyte compartment.

Measuring thymopoiesis and the contribution of recent thymic emigrants to the naive T-cell pool after HSCT is not straightforward. Although increased TREC contents at first sight seem suggestive for increased thymic output, T-cells bearing TRECs may in fact be overrepresented in the peripheral T-cell pool post-transplantation when cell numbers are low ${ }^{28}$. Hence, for naive $\mathrm{CD} 4^{+} \mathrm{T}$ cells, whose numbers had not yet normalized, increased average TREC contents may incorrectly be interpreted as evidence for increased thymic output. The finding that the average TREC content of naive $\mathrm{CD} 4^{+} \mathrm{T}$-cells following autoHSCT was higher than in age-matched controls provides no evidence that thymic output following transplantation was higher than in healthy controls, but does imply that the thymus had become functional again within 12 months after intense conditioning for autoHSCT. The fact that the average TREC content of naive $C D 4^{+} \mathrm{T}$-cells, but not that of naive $\mathrm{CD} 8^{+} \mathrm{T}$-cells, was higher in patients than in healthy individuals may reflect differences in the degree of depletion of naive $\mathrm{CD} 4^{+}$and $\mathrm{CD} 8^{+} \mathrm{T}$-cells. Alternatively, it might reflect differences in the way $\mathrm{CD} 4^{+}$and $\mathrm{CD} 8^{+} \mathrm{T}$-cells are generated. In support of the latter explanation, repertoire analyses in patients receiving an autoHSCT 
medRxiv preprint doi: https://doi.org/10.1101/2020.04.24.20078295; this version posted June 8, 2020. The copyright holder for this preprint (which was not certified by peer review) is the author/funder, who has granted medRxiv a license to display the preprint in perpetuity.

All rights reserved. No reuse allowed without permission.

for the treatment of autoimmune diseases have suggested that $\mathrm{CD} 4^{+} \mathrm{T}$-cells largely arise de novo, since most $\mathrm{CD} 4^{+} \mathrm{T}$-cell clones post-autoHSCT were not present at baseline, while $\mathrm{CD} 8^{+} \mathrm{T}$-cells mainly expand from cells that were already circulating pre-transplantation ${ }^{38-40}$.

To study in a population other than T-cells whether lymphocyte production and loss rates in humans are regulated in a density-dependent manner, we quantified the production and loss rates of different B-cell subsets. In line with previous reports ${ }^{41-43}$, we found that 12 months after transplantation, naive B-cell numbers had reconstituted to healthy (or even higher than healthy) control values, while Ig class-switched and $\mathrm{IgM}^{+}$memory B-cells had not yet fully recovered. The delayed reconstitution of Ig class-switched and $\operatorname{lgM}^{+}$memory B-cells has typically been attributed to treatment-related damage to secondary lymphoid organs, which may hamper the formation of germinal centers essential for somatic hypermutation and isotype switching ${ }^{42}$. Also for naive, Ig classswitched, and $\operatorname{lgM}^{+}$memory B-cells, we found that not only production rates but also cell loss rates were increased 12 months post-autoHSCT, further supporting our conclusion that increased lymphocyte production rates do not simply reflect a homeostatic response to low lymphocyte numbers.

In brief, our findings show that despite the slow reconstitution of lymphocytes in autoHSCT patients, lymphocyte production rates are increased is. Since this increased production goes hand in hand with increased cell loss, and does not normalize when cell numbers do, it is not simply due to homeostatic mechanisms. Future studies should address whether the dynamics of lymphocytes after autoHSCT normalize in the long run, what drives the increase in lymphocyte production and loss rates during immune reconstitution, and to what extent immune reconstitution in the tissues occurs.

\section{Acknowledgments}

We thank the patients for their participation in this study, Jeroen F. van Velzen, Pien A.J. van der Burght and Gerrit Spierenburg for assistance with cell sorting, Laura Ackermans for theoretical input, Lyanne Derksen for critically reading the manuscript, Mr Benjamin Bartol and Ms Pei Mun Aui for technical support, and the nurses from the Julius Center Trial Unit for taking care of study participants.

\section{Funding}

The research leading to these results has received funding from the European Union Seventh Framework Programme (FP7/2007-2013) through the Marie-Curie Action "Quantitative T cell Immunology" Initial Training Network, with reference number FP7-PEOPLE-2012-ITN 317040-QuanTI and from the Landsteiner Foundation for Blood Transfusion Research (LSBR grant 0812). 
medRxiv preprint doi: https://doi.org/10.1101/2020.04.24.20078295; this version posted June 8, 2020. The copyright holder for this preprint (which was not certified by peer review) is the author/funder, who has granted medRxiv a license to display the preprint in perpetuity.

All rights reserved. No reuse allowed without permission.

\section{Authorship}

Contribution: MB-P, VvH, JD, JB and KT designed the experiments; MB-P and VvH performed the experiments; LvdW and AJ selected and included the patients; MB-P, VH, JD, RdB, JB and KT analysed and interpreted data; JD, RdB, and JB performed mathematical modelling; and all authors wrote and approved the manuscript.

\section{Conflict-of-interest statements}

The authors declare no competing financial interests.

\section{References}

1. Lin Y, Kim J, Metter EJ, et al. Changes in blood lymphocyte numbers with age in vivo and their association with the levels of cytokines/cytokine receptors. Immun. Ageing. 2016;13(1):24.

2. Wertheimer AM, Bennett MS, Park B, et al. Aging and Cytomegalovirus Infection Differentially and Jointly Affect Distinct Circulating T Cell Subsets in Humans. J. Immunol. 2014;192(5):2143-2155.

3. Freitas AA, Rocha B. Population Biology of Lymphocytes: The Flight for Survival. Annu. Rev. Immunol. 2000;18(1):83-111.

4. Miller R a, Stutman O. T cell repopulation from functionally restricted splenic progenitors: 10,000 -fold expansion documented by using limiting dilution analyses. J. Immunol. 1984;133(6):2925-32.

5. Bell EB, Sparshott SM, Drayson MT, Ford WL. The stable and permanent expansion of functional T lymphocytes in athymic nude rats after a single injection of mature T cells. J. Immunol. 1987;139(5):137984.

6. Neujahr DC, Chen C, Huang X, et al. Accelerated Memory Cell Homeostasis during T Cell Depletion and Approaches to Overcome It. J. Immunol. 2006;176(8):4632-4639.

7. Gaudin E, Rosado M, Agenes F, McLean A, Freitas AA. B-cell homeostasis, competition, resources, and positive selection by self-antigens. Immunol. Rev. 2004;197:102-15.

8. Heining C, Spyridonidis A, Bernhardt E, et al. Lymphocyte reconstitution following allogeneic hematopoietic stem cell transplantation: a retrospective study including 148 patients. Bone Marrow Transplant. 2007;39(10):613-622.

9. Ringhoffer S, Rojewski M, Dohner H, Bunjes D, Ringhoffer M. T-cell reconstitution after allogeneic stem cell transplantation: assessment by measurement of the sjTREC/ TREC ratio and thymic naive T cells. Haematologica. 2013;98(10):1600-1608.

10. Bosch M, Khan FM, Storek J. Immune reconstitution after hematopoietic cell transplantation. Curr. Opin. Hematol. 2012;19(4):324-335.

11. Williams KM, Hakim FT, Gress RE. T cell immune reconstitution following lymphodepletion. Semin. 
medRxiv preprint doi: https://doi.org/10.1101/2020.04.24.20078295; this version posted June 8, 2020. The copyright holder for this preprint (which was not certified by peer review) is the author/funder, who has granted medRxiv a license to display the preprint in perpetuity.

All rights reserved. No reuse allowed without permission.

Immunol. 2007;19(5):318-330.

12. Jones JL, Thompson SAJ, Loh $\mathrm{P}$, et al. Human autoimmunity after lymphocyte depletion is caused by homeostatic T-cell proliferation. Proc. Natl. Acad. Sci. 2013;110(50):20200-20205.

13. Bouvy AP, Kho MML, Klepper M, et al. Kinetics of homeostatic proliferation and thymopoiesis after ratg induction therapy in kidney transplant patients. Transplantation. 2013;96(10):904-913.

14. Hazenberg MD. T-cell receptor excision circle and T-cell dynamics after allogeneic stem cell transplantation are related to clinical events. Blood. 2002;99(9):3449-3453.

15. Alho AC, Kim HT, Chammas MJ, et al. Unbalanced recovery of regulatory and effector $\mathrm{T}$ cells after allogeneic stem cell transplantation contributes to chronic GVHD. Blood. 2017;127(5):646-658.

16. Westera L, van Hoeven V, Drylewicz J, et al. Lymphocyte maintenance during healthy aging requires no substantial alterations in cellular turnover. Aging Cell. 2015;14(2):219-227.

17. R Core Team (R Foundation for Statistical Computing). R: A Language and Environment for Statistical Computing. 2018;

18. Van Gent R, Schadenberg AWL, Otto SA, et al. Long-term restoration of the human T-cell compartment after thymectomy during infancy: A role for thymic regeneration? Blood. 2011;118(3):627-634.

19. Sauce D, Larsen M, Fastenackels S, et al. Lymphopenia-Driven Homeostatic Regulation of Naive T Cells in Elderly and Thymectomized Young Adults. J. Immunol. 2012;189(12):5541-5548.

20. Fry TJ, Connick E, Falloon J, et al. A potential role for interleukin-7 in T-cell homeostasis. Blood. 2001;97(10):2983-90.

21. Napolitano LA, Grant RM, Deeks SG, et al. Increased production of IL-7 accompanies HIV-1-mediated Tcell depletion: implications for T-cell homeostasis. Nat. Med. 2001;7(1):73-79.

22. Bolotin E, Annett G, Parkman R, Weinberg K. Serum levels of IL-7 in bone marrow transplant recipients: relationship to clinical characteristics and lymphocyte count. Bone Marrow Transplant. 1999;23(8):783788.

23. Douek DC, McFarland RD, Keiser PH, et al. Changes in thymic function with age and during the treatment of HIV infection. Nature. 1998;396(6712):690-695.

24. Hazenberg MD, Otto SA, Cohen Stuart JW, et al. Increased cell division but not thymic dysfunction rapidly affects the T-cell receptor excision circle content of the naive T cell population in HIV-1 infection. Nat. Med. 2000;6(9):1036-42.

25. Hazenberg MD, Verschuren MC, Hamann D, Miedema F, Dongen JJ. T cell receptor excision circles as markers for recent thymic emigrants: Basic aspects, technical approach, and guidelines for interpretation. J. Mol. Med. 2001;79(11):631-640.

26. Kohler S, Thiel A. Life after the thymus: CD31+ and CD31- human naive CD4+ T-cell subsets. Blood. 2009;113(4):769-774.

27. van den Broek T, Borghans JAM, van Wijk F. The full spectrum of human naive T cells. Nat. Rev. Immunol. 2018;18(June):

28. Hazenberg MD, Borghans JAM, de Boer RJ, Miedema F. Thymic output: a bad TREC record. Nat. Immunol. 2003;4(2):97-99. 
medRxiv preprint doi: https://doi.org/10.1101/2020.04.24.20078295; this version posted June 8, 2020. The copyright holder for this preprint (which was not certified by peer review) is the author/funder, who has granted medRxiv a license to display the preprint in perpetuity.

All rights reserved. No reuse allowed without permission.

29. Havenith SHC, Remmerswaal EBM, Bemelman FJ, et al. Rapid T cell repopulation after rabbit antithymocyte globulin (rATG) treatment is driven mainly by cytomegalovirus. Clin. Exp. Immunol. 2012;169(3):292-301.

30. Bouvy AP, Klepper M, Betjes MGH, et al. Alemtuzumab as Antirejection Therapy. Transplant. Direct. 2016;2(6):e83.

31. Ponchel F, Cuthbert RJ, Goëb V. IL-7 and lymphopenia. Clin. Chim. Acta. 2011;412(1-2):7-16.

32. Brugnoni $D$, Airò $P$, Pennacchio $M$, et al. Immune reconstitution after bone marrow transplantation for combined immunodeficiencies: down-modulation of Bcl-2 and high expression of CD95/Fas account for increased susceptibility to spontaneous and activation-induced lymphocyte cell death. Bone Marrow Transplant. 1999;23(5):451-457.

33. Lin MT, Tseng LH, Frangoul H, et al. Increased apoptosis of peripheral blood T cells following allogeneic hematopoietic cell transplantation. Blood. 2000;95(12):3832-9.

34. Poulin J-F. Evidence for adequate thymic function but impaired naive T-cell survival following allogeneic hematopoietic stem cell transplantation in the absence of chronic graft-versus-host disease. Blood. 2003;102(13):4600-4607.

35. Storek J, Geddes M, Khan F, et al. Reconstitution of the immune system after hematopoietic stem cell transplantation in humans. Semin. Immunopathol. 2008;30(4):425-37.

36. Cho BK, Rao VP, Ge Q, Eisen HN, Chen J. Homeostasis-stimulated proliferation drives naive T cells to differentiate directly into memory T cells. J. Exp. Med. 2000;192(4):549-56.

37. Goldrath AW, Bogatzki LY, Bevan MJ. Naive T cells transiently acquire a memory-like phenotype during homeostasis-driven proliferation. J. Exp. Med. 2000;192(4):557-64.

38. Muraro PA, Douek DC, Packer A, et al. Thymic output generates a new and diverse TCR repertoire after autologous stem cell transplantation in multiple sclerosis patients. J. Exp. Med. 2005;201(5):805-816.

39. Muraro PA, Robins H, Malhotra S, et al. T cell repertoire following autologous stem cell transplantation for multiple sclerosis. J. Clin. Invest. 2014;124(3):1168-72.

40. Dubinsky AN, Burt RK, Martin R, Muraro PA. T-cell clones persisting in the circulation after autologous hematopoietic SCT are undetectable in the peripheral CD34+ selected graft. Bone Marrow Transplant. 2010;45(2):325-331.

41. Burns LJ, Weisdorf DJ, DeFor TE, et al. IL-2-based immunotherapy after authologous transplantation for lymphoma and breast cancer induces immune activation and cytokine release: A phase I/II trial. Bone Marrow Transplant. 2003;32(2):177-186.

42. Avanzini MA, Locatelli F, Santos C Dos, et al. B lymphocyte reconstitution after hematopoietic stem cell transplantation: functional immaturity and slow recovery of memory CD27+ B cells. Exp. Hematol. 2005;33(4):480-486.

43. Bemark M, Holmqvist J, Abrahamsson J, Mellgren K. Translational Mini-Review Series on B cell subsets in disease. Reconstitution after haematopoietic stem cell transplantation - revelation of $B$ cell developmental pathways and lineage phenotypes. Clin. Exp. Immunol. 2012;167(1):15-25. 
medRxiv preprint doi: https://doi.org/10.1101/2020.04.24.20078295; this version posted June 8,2020 . The copyright holder for this preprint (which was not certified by peer review) is the author/funder, who has granted medRxiv a license to display the preprint in perpetuity.

\section{A}

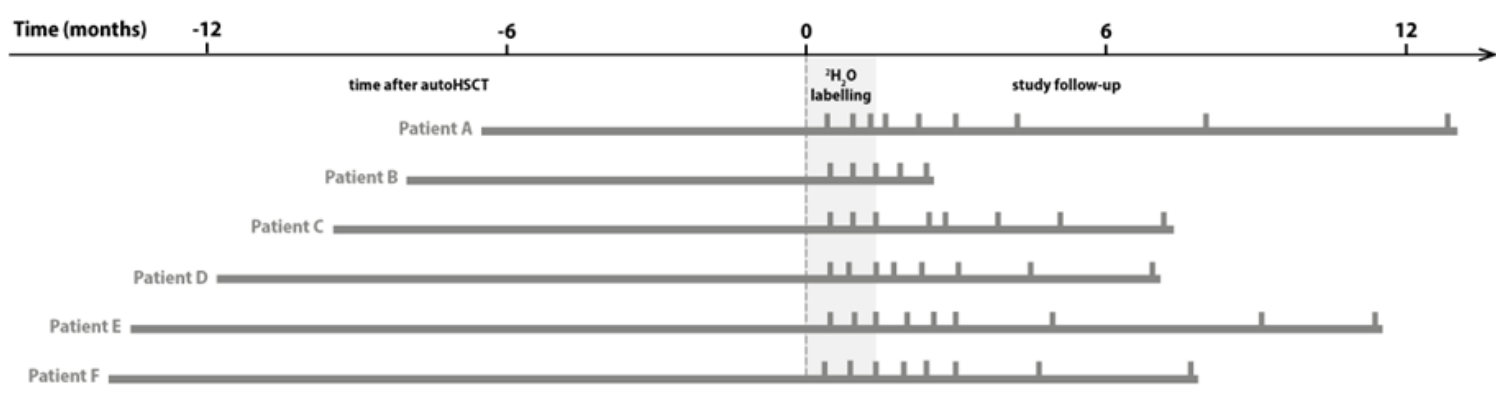

B

\begin{tabular}{|c|c|c|c|c|c|c|c|c|}
\hline Patient & Symbol & Age & Sex & Malignancy & $\begin{array}{c}\text { Induction } \\
\text { therapy }\end{array}$ & $\begin{array}{c}\text { Conditioning } \\
\text { Regimen }\end{array}$ & $\begin{array}{c}\text { Time post- } \\
\text { HSCT }\end{array}$ & $\begin{array}{c}\text { Medication } \\
\text { usage }\end{array}$ \\
\hline A & O & 27 & M & $\begin{array}{c}\text { Acute myeloid } \\
\text { leukemia }\end{array}$ & $\begin{array}{c}\text { HOVON } 132 \mathrm{arm} \\
\mathrm{A}\end{array}$ & $\begin{array}{c}\text { Busulfan, } \\
\text { Cyclosporine }\end{array}$ & 196 days & Valaciclovir \\
\hline B & 0 & 53 & $\mathrm{~F}$ & Multiple myeloma & $\begin{array}{c}\text { VCD, VMP-arm, } \\
\text { VRD }\end{array}$ & Melphalan & 245 days & Pamidronate \\
\hline C & $\bullet$ & 61 & M & $\begin{array}{c}\text { Non Hodgkin } \\
\text { lymphoma (mantle } \\
\text { cell lymphoma) }\end{array}$ & R-CHOP, Ara-C & BEAM & 287 days & Triamterene \\
\hline D & O & 57 & $M$ & Multiple myeloma & TAD & Melphalan & 355 days & Omeprazole \\
\hline $\mathbf{E}$ & O & 51 & $M$ & Multiple myeloma & VRD & Melphalan & 414 days & - \\
\hline $\mathbf{F}$ & ○ & 54 & $M$ & Multiple myeloma & CTD & Melphalan & 420 days & Tamsulosin \\
\hline
\end{tabular}

Figure 1. Study protocol timeline and patient characteristics. (A) Summary figure depicting the study

438 time line of every patient. Patients are centred by start of ${ }^{2} \mathrm{H}_{2} \mathrm{O}$ labelling. The left bar indicated the

439 time between the autologous hematopoietic stem cell transplantation (autoHSCT) and the start of the

440 labelling period, the grey area indicates the 6 weeks ${ }^{2} \mathrm{H}_{2} \mathrm{O}$ labelling period, the right bar provides the

441 follow up period and the vertical bars indicate the blood sampling time points. (B) Patient

442 characteristics. Age=Age at start ${ }^{2} \mathrm{H}_{2} \mathrm{O}$ labelling; $\mathrm{M}=$ Male; $\mathrm{F}=$ Female; Time post-HSCT=Reconstitution

443 period at start ${ }^{2} \mathrm{H}_{2} \mathrm{O}$ labelling; Medication usage=Medication during the study; HOVON 132 arm A

444 (Idarubicin, Ara-C (Cytarabine), Daunorubicin); VCD (Bortezomib, Cyclophosphamide, Dexamethason);

445 VMP (Bortezomib, Melphalan, Prednisone); VRD (Bortezomib, lenalidomide, dexamethasone); R-CHOP

446 (Rituximab, Cyclophosphamide, Adriamycin, Vincristin, Prednisone); Ara-C (Cytarabine), TAD

447 (Thalidomide, Adriamycin,Dexamethasone); CTD (Carfilzomib, Thalidomide, Dexamethasone); BEAM

448 (Carmustine, Etoposide, Ara-C (Cytarabine), Melphalan). For absolute leukocytes, neutrophils,

449 lymphocytes and monocytes numbers see Sup. Figure 6. 
medRxiv preprint doi: https://doi.org/10.1101/2020.04.24.20078295; this version posted June 8, 2020. The copyright holder for this preprint (which was not certified by peer review) is the author/funder, who has granted medRxiv a license to display the preprint in perpetuity.

All rights reserved. No reuse allowed without permission.

A

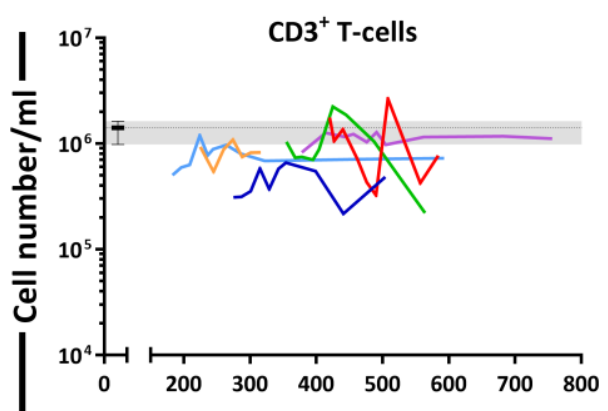

B

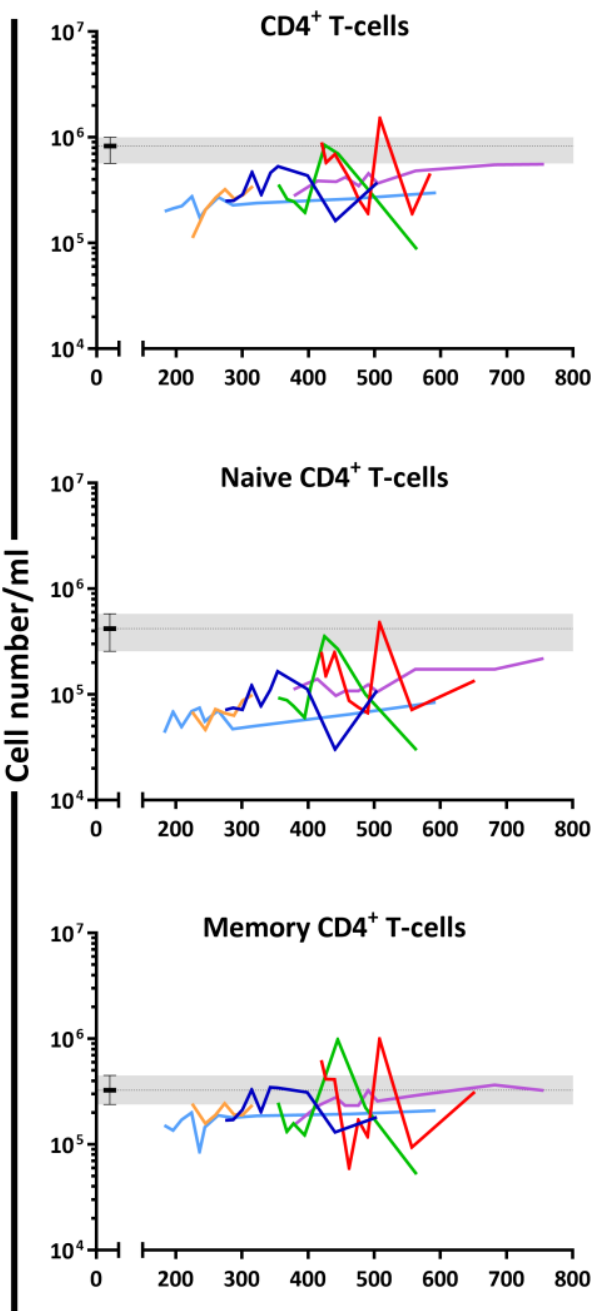

C

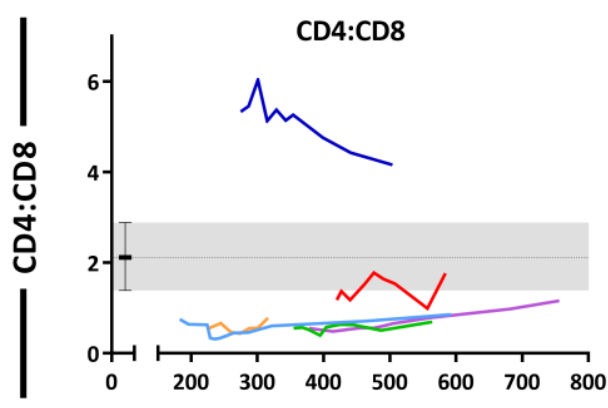

D

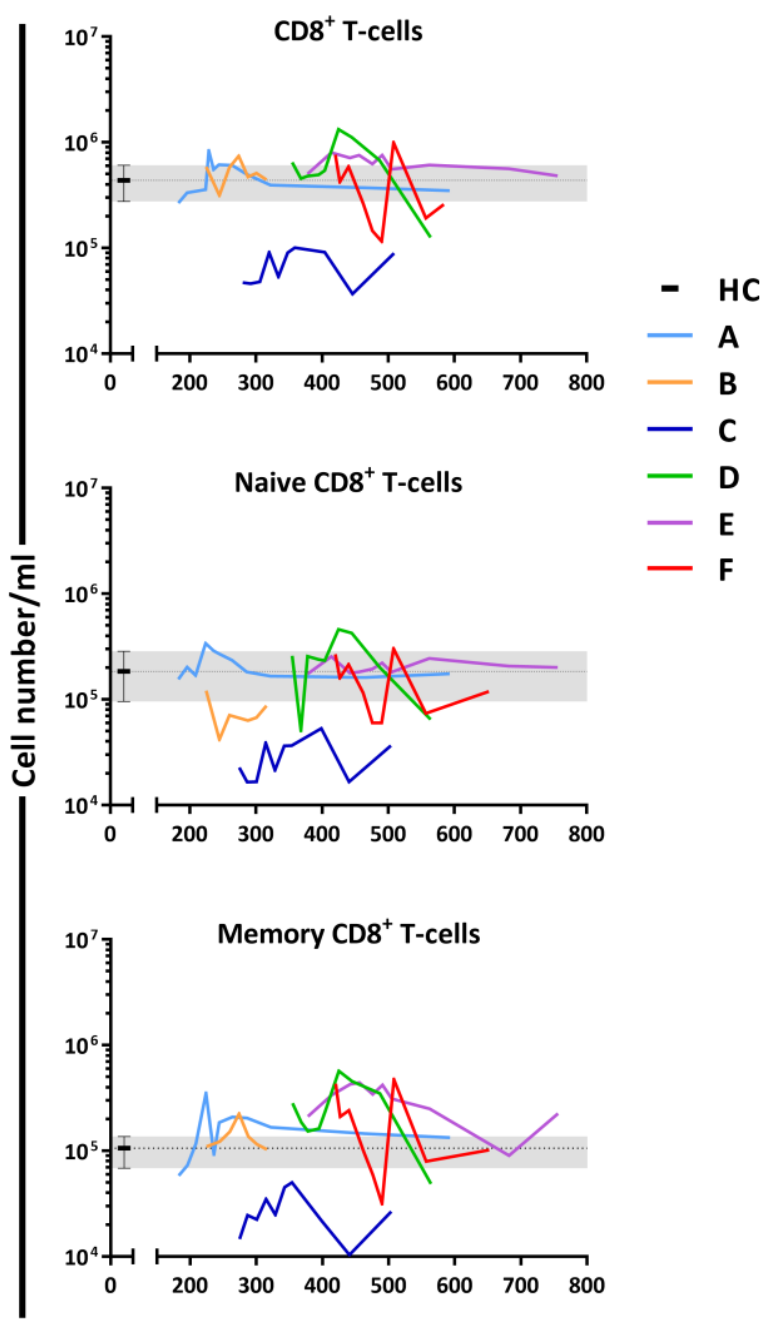

Time post autoHSCT (days)

\section{E}

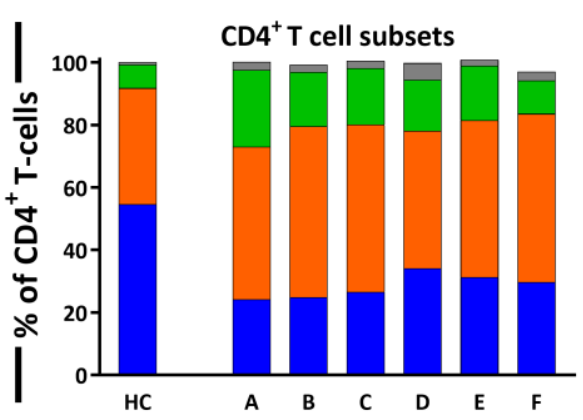

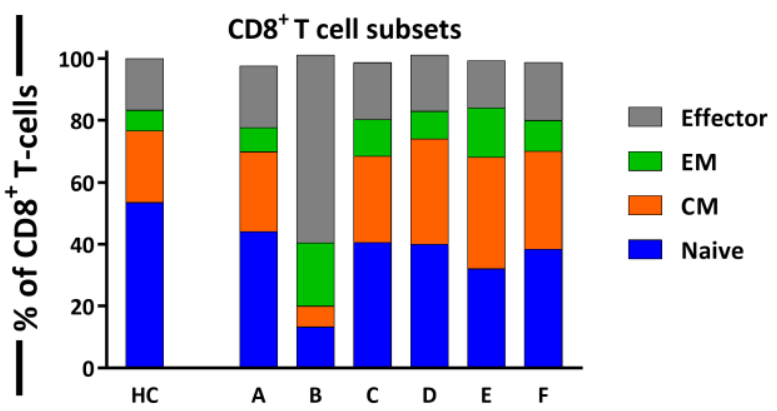


medRxiv preprint doi: https://doi.org/10.1101/2020.04.24.20078295; this version posted June 8, 2020. The copyright holder for this preprint (which was not certified by peer review) is the author/funder, who has granted medRxiv a license to display the preprint in perpetuity.

All rights reserved. No reuse allowed without permission.

451 Figure 2. T-cell reconstitution following autoHSCT. (A) Absolute numbers (cells per milliliter) of total

$452 \mathrm{CD}^{+} \mathrm{T}$-cells. (B) Absolute numbers (cells per milliliter) of $\mathrm{CD}^{+}{ }^{+}$-cells $\left(\mathrm{CD}^{+}{ }^{+} \mathrm{CD} 4^{+}\right)$, naive $\left(\mathrm{CD} 27^{+} \mathrm{CD} 45 \mathrm{RO}^{-}\right.$

453 ) and memory (CD45RO ${ }^{+}$) CD4 ${ }^{+}$T-cells. (C) CD4:CD8 ratio. (D) Absolute numbers (cells per milliliter) of $454 \mathrm{CD}^{+}$T-cells $\left(\mathrm{CD}^{+}{ }^{+} \mathrm{CD}^{+}\right)$, naive $\left(\mathrm{CD} 27^{+} \mathrm{CD} 45 \mathrm{RO}^{-}\right)$and memory (CD45RO $\left.{ }^{+}\right) \mathrm{CD}^{+}$T-cells. (A-D) Graphs 455 show the absolute cell counts per milliliter or the CD4:CD8 ratio in autoHSCT patients (patients A to F) 456 over time from for the duration of the study, and the median and the corresponding IR for HCs (healthy 457 controls, grey area and whisker bars). (E) Bar graphs show the median percentage of naive

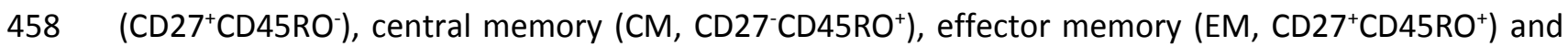
459 effector ( $\left.\mathrm{CD} 27^{-} \mathrm{CD}^{2} 5 \mathrm{RO}^{-}\right) \mathrm{CD}^{+}$and $\mathrm{CD} 8^{+}$T-cells of autoHSCT patients (patients $\mathrm{A}$ to $\mathrm{F}$ ) and HCs (naive 460 in blue, CM in orange, EM in green and effector in grey). For patient characteristics see Figure 1B, for the T-cell subset distribution per patient over time see Sup. Figure 3. 
medRxiv preprint doi: https://doi.org/10.1101/2020.04.24.20078295; this version posted June 8, 2020. The copyright holder for this preprint (which was not certified by peer review) is the author/funder, who has granted medRxiv a license to display the preprint in perpetuity.
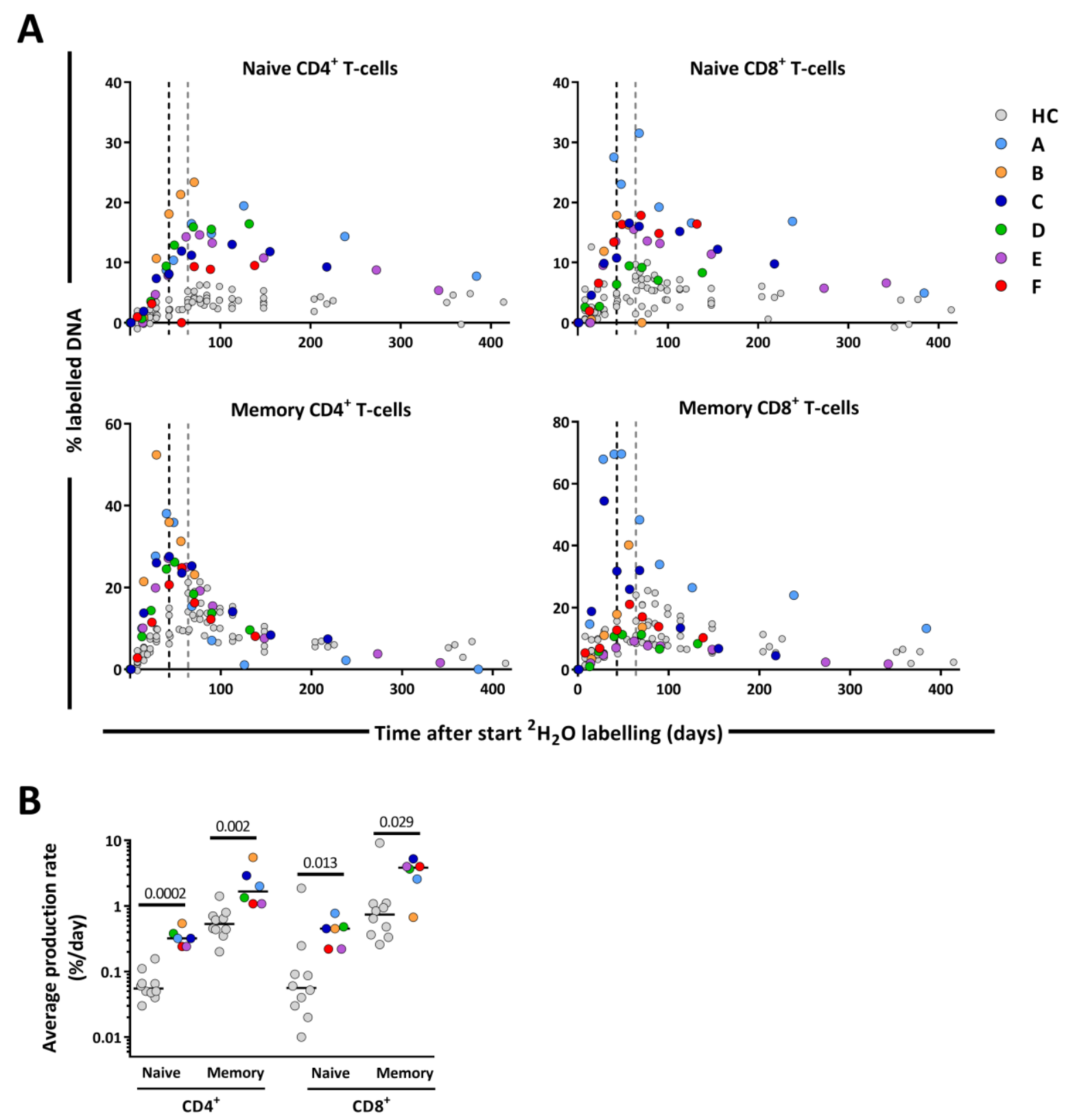

Figure 3. T-cell dynamics after autoHSCT. (A) Deuterium enrichment in the DNA of naive and memory $\mathrm{CD}^{+}$and $\mathrm{CD} 8^{+}$T-cells in autoHSCT patients ( $\mathrm{A}$ to $\mathrm{F}$, color symbols), and healthy controls (HCs, grey symbols) ${ }^{16}$. Dotted lines correspond to the end of the labelling period (black for autoHSCT patients and grey for $\mathrm{HCs}$ ). Label enrichment was scaled between 0 and $100 \%$ by normalizing for the maximum enrichment in granulocytes (Sup. Figure 7). For individual fits see Sup. Figure 8. (B) Estimates of the per cell production rate of naive and memory $\mathrm{CD} 4^{+}$and $\mathrm{CD} 8^{+}$T-cells in autoHSCT patients and HCs ${ }^{16}$. Different symbols indicate different individuals, autoHSCT patients (A to F) in color and HCs in grey. Horizontal lines represent median values. P-values of significant differences between groups are shown. 
A
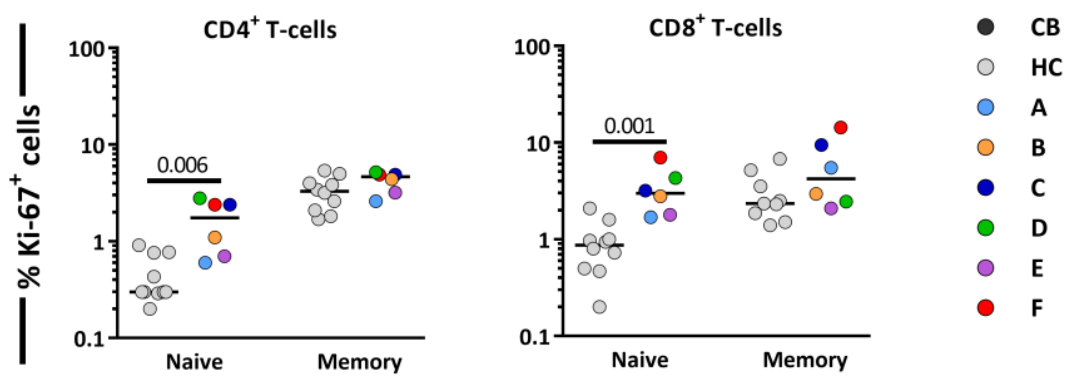

B
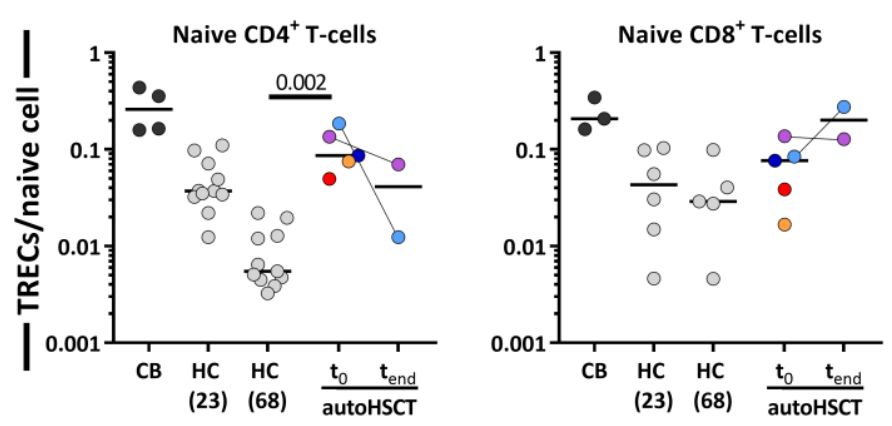

C

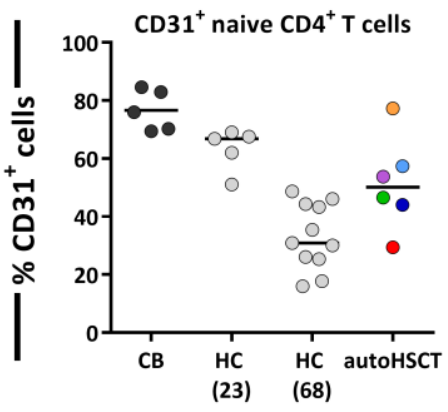

472

473 Figure 4. Contribution of peripheral proliferation and thymic output to T-cell production after

474 autoHSCT. (A) Ki-67 expression was measured within naive and memory CD4 ${ }^{+}$(left panel) and CD8 ${ }^{+}$

475 (right panel) T-cell in autoHSCT patients and HCs ${ }^{16}$. (B) Average number of TRECs per naive CD4 ${ }^{+}$(left 476 panel) and $\mathrm{CD}^{+}$(right panel) T-cell in autoHSCT patients, cord blood (CB) and healthy controls (HCs)

$477{ }^{16}$. For Patient $A$ and Patient $E$, TREC content was measured the first day of the study $\left(t_{0}\right)$ as well as the 478 last study visit ( $t_{\text {end }}$ ). For Patient $D$, TREC content was not successfully measured due to limited 479 material. (C) CD31 expression was measured within naive CD4 ${ }^{+}$T-cells in autoHSCT patients, cord blood 480 and $\mathrm{HCs}{ }^{16}$. For changes in CD31 expression and absolute numbers of $\mathrm{CD} 31^{+}$cells over time, see Sup. 481 Figure 4. Different symbols indicate different individuals, autoHSCT patients (A to F) in color, CB in dark 482 grey, and young (median age of 23 years) and old (median age of 68 years) HCs in light grey. Horizontal 483 lines represent median values. P-values of significant differences between groups are shown. 
medRxiv preprint doi: https://doi.org/10.1101/2020.04.24.20078295; this version posted June 8, 2020. The copyright holder for this preprint (which was not certified by peer review) is the author/funder, who has granted medRxiv a license to display the preprint in perpetuity.

All rights reserved. No reuse allowed without permission.
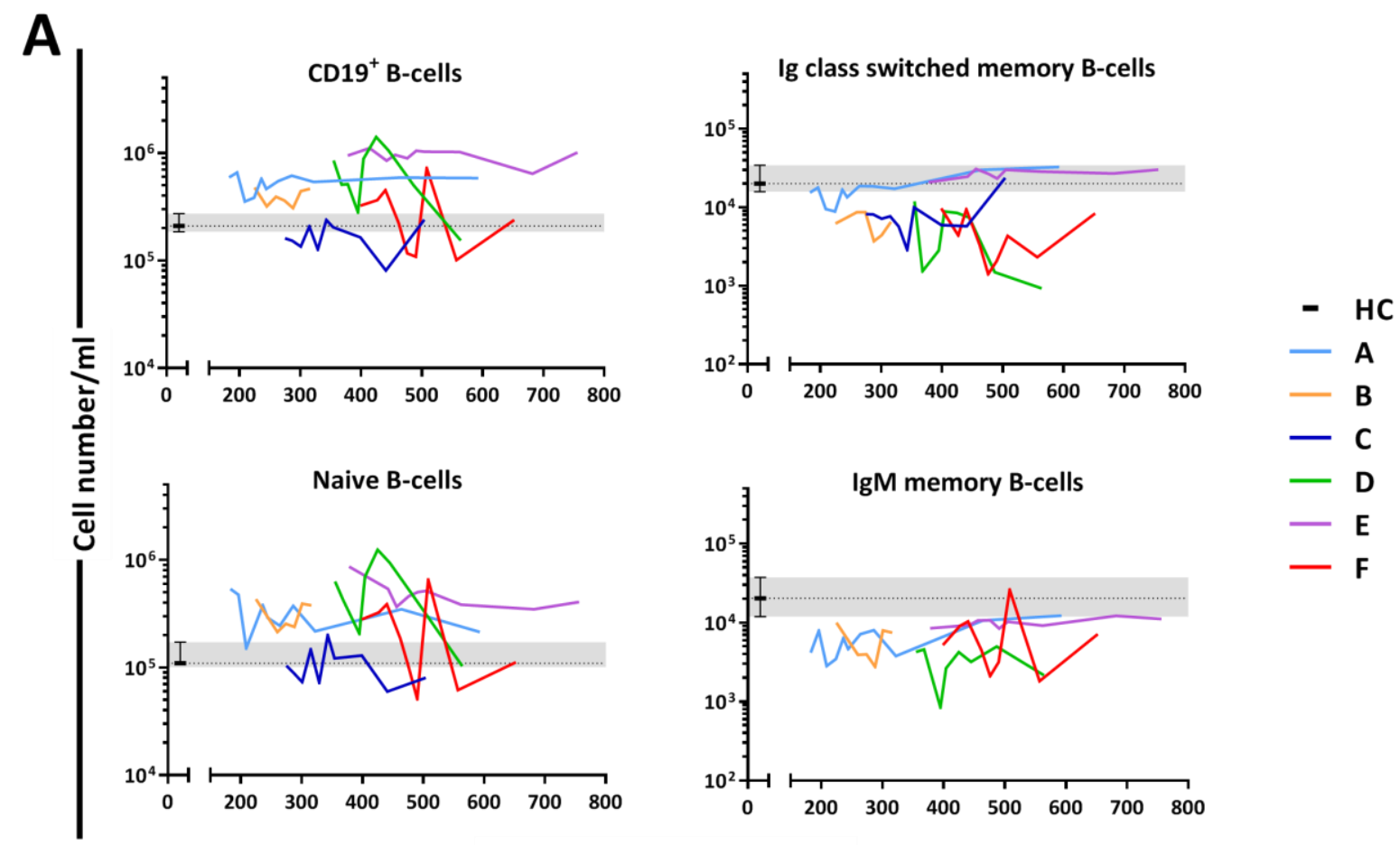

Time post autoHSCT (days)

B

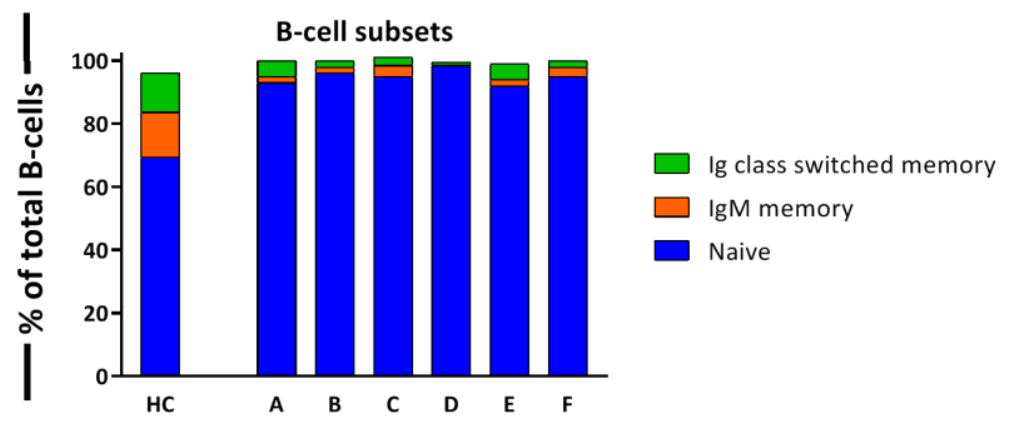

Figure 5. B-cell reconstitution following autoHSCT. (A) Absolute numbers (cells per milliliter) of total CD19+ $\mathrm{B}$-cells, naive $\left(\mathrm{CD}_{19}{ }^{+} \mathrm{IgM}^{+} \mathrm{CD} 27^{-}\right)$, Ig class-switched memory $\left(\mathrm{CD}^{1} 9^{+} \operatorname{IgM} \mathrm{CD}^{-} 7^{+}\right)$and $\operatorname{lgM}^{+}$memory $\left(\mathrm{CD} 19^{+} \mathrm{gMM}^{+} \mathrm{CD} 27^{+}\right) \mathrm{B}$-cells in peripheral blood over time. Graphs show the absolute cell counts per milliliter in autoHSCT patients (patients A to F) over the duration of the study, and the median and the corresponding IR (interquartile rage) for HCs (healthy controls, grey area and whisker bars). (B) Bar graphs show the median percentage of naive, Ig class-switched memory and $\operatorname{lgM}^{+}$memory B-cells within total $\mathrm{CD} 19^{+} \mathrm{B}$-cells of autoHSCT patients (patients $\mathrm{A}$ to $\mathrm{F}$ ) and HCs (naive in blue, natural effector in orange and memory in green). For the B-cell subset distribution per patient over time see Sup. Figure 5. Note the different $y$-axes in panel A. 
medRxiv preprint doi: https://doi.org/10.1101/2020.04.24.20078295; this version posted June 8, 2020. The copyright holder for this preprint (which was not certified by peer review) is the author/funder, who has granted medRxiv a license to display the preprint in perpetuity.

All rights reserved. No reuse allowed without permission.

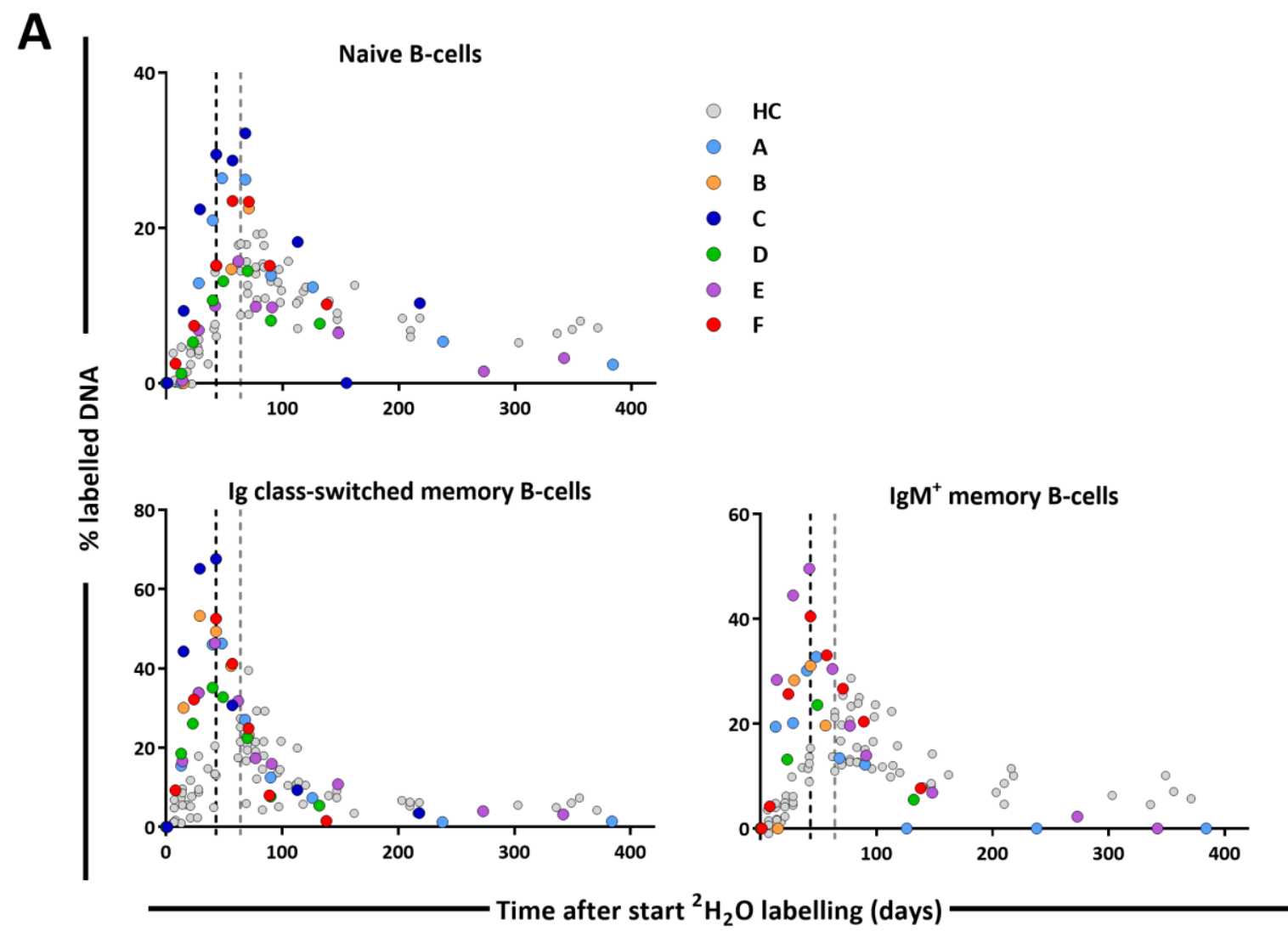

B

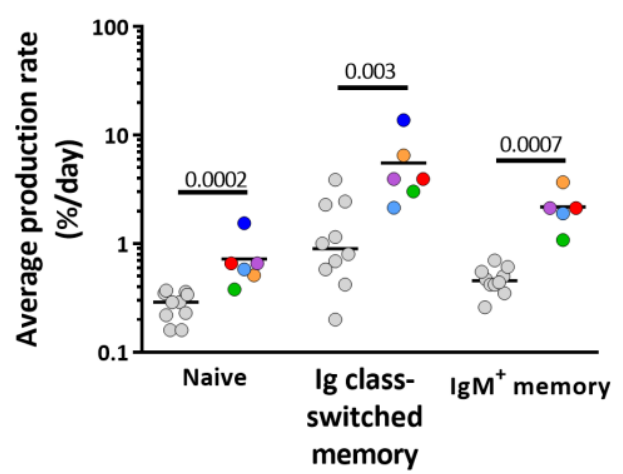

D
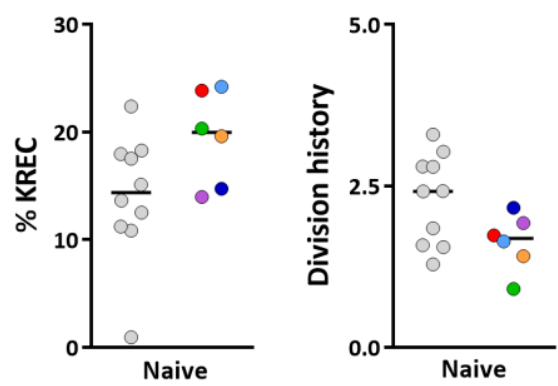

C

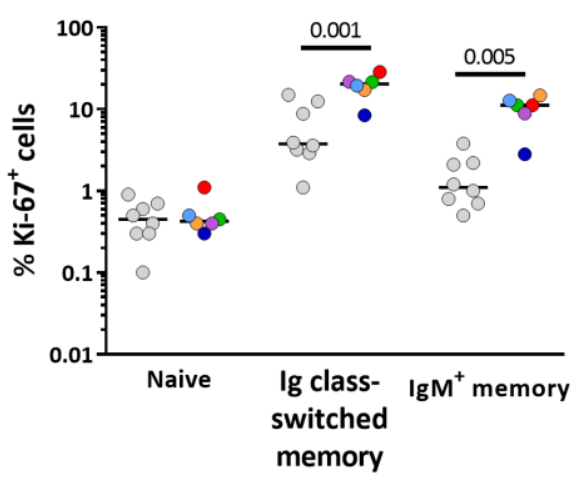

Figure 6. B-cell dynamics after autoHSCT. (A) Deuterium enrichment in the DNA of naive, Ig class-

switched memory and $\operatorname{IgM}^{+}$memory B-cells in autoHSCT patients (A to $\mathrm{F}$, color symbols), and healthy controls (HCs, grey symbols) ${ }^{16}$. Dotted lines correspond to the end of the labelling period (black for 
medRxiv preprint doi: https://doi.org/10.1101/2020.04.24.20078295; this version posted June 8,2020 . The copyright holder for this preprint (which was not certified by peer review) is the author/funder, who has granted medRxiv a license to display the preprint in perpetuity.

All rights reserved. No reuse allowed without permission.

A

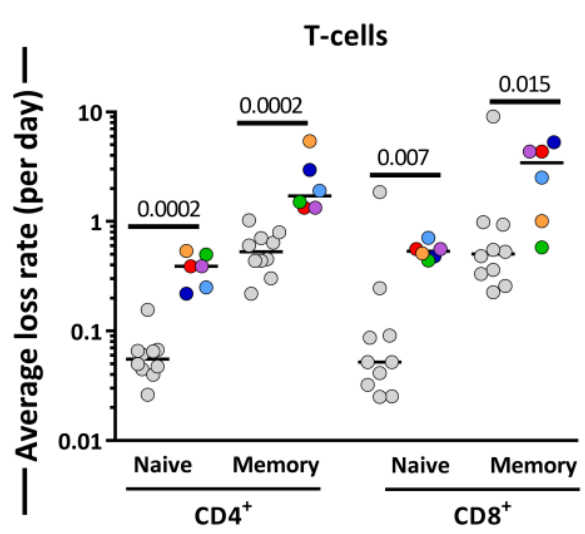
autoHSCT patients and grey for HCs). Label enrichment was scaled between 0 and $100 \%$ by normalizing for the maximum enrichment in granulocytes for each patient (Sup. Figure 8). For individual fits see Sup. Figure 9. (B) Estimates of the per cell production rates of naive, Ig class-switched memory and $\mathrm{IgM}^{+}$memory B-cells in autoHSCT patients and $\mathrm{HCs}^{16}$. (C) $\mathrm{Ki}-67$ expression was measured within naive, Ig class-switched memory and $\operatorname{lgM}^{+}$memory B-cells in autoHSCT patients and HCs ${ }^{16}$. (D) Percentage of naive B-cells containing a KREC and naive B-cell replication history for autoHSCT patients and HCs ${ }^{16}$. Different symbols indicate different individuals, autoHSCT patients (A to $F$ ) in color and HCs in grey. Horizontal lines represent median values. P-values of significant differences between groups are shown.

507

508

509

510

511

512

513

514

515

516

517

518

519
B

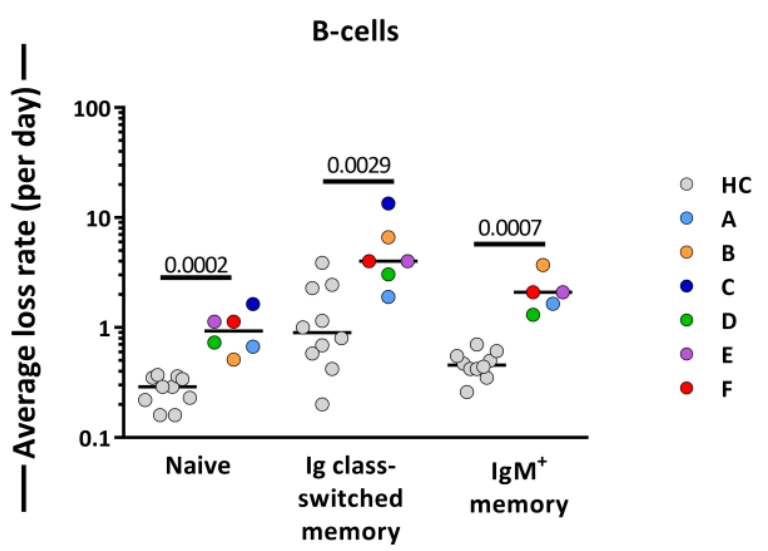

Figure 7. Average T-cell and B-cell loss rates following autoHSCT. (A) Estimates of the average loss rates of naive and memory $\mathrm{CD} 4^{+}$and $\mathrm{CD} 8^{+} \mathrm{T}$-cells and of $(\mathrm{B})$ naive, Ig class-switched memory and $\mathrm{IgM}^{+}$ memory B-cells in autoHSCT patients ( $\mathrm{A}$ to $\mathrm{F}$, color symbols), and healthy controls ( $\mathrm{HC}$, grey symbols) ${ }^{16}$. Average loss rates were calculated using the estimated average turnover rates and the corrected cell numbers (Sup. Figure 10 and 11) as described in supplementary material and methods. Horizontal lines represent median values. P-values of significant differences between groups are shown. 